\title{
Veri ve Olasılık Öğrenme Alanlarında Yapılıış Çalışmaların İçerik Analizi
}

\author{
Tuğba Tosun ${ }^{* 1}$ ve Deniz Özen Ünal ${ }^{2}$
}

Öz

Bu araștırmada; Matematik Dersi Öğretim Programı yer alan veri işleme ve olasılık öğrenme alanlarına yönelik alan yazında yer alan araştırma eğilimlerini incelemek amaçlanmıştır. Bu amaçla Türkiye'de yapılan ortaokul düzeyinde 34 bilimsel makale, 24 yüksek lisans ve 3 doktora tezi olmak üzere toplam 61 çalışma taranıp içerik analizi yapılmıştır. İlgili çalışmalara ulaşabilmek için; olasılık, veri işleme, grafik kavramları ile istatistiksel düşünme ve istatistiksel okuryazarlık kavramları çerçevesinde tarama yapılmıștır. Araştırmanın bulguları anahtar kelimeler, araştırma yöntemleri, araștırma desenleri, örneklem büyüklüğ̈̈, veri toplama araçları, veri analiz yöntemleri ve araştırmaların amaç ve sonuçlarını kapsayacak șekilde temalara ayrılmıștır. Veriler, yüzde ve frekansa dayalı olarak yorumlanmıș, bulgular tablolarla sunulmuştur. Elde edilen bulgulara dayanarak, yapılan araştırmaların çoğunluğunun Veri ve Olasılık öğrenme alanlarında kullanılabilecek ögretim yöntemlerinin etkililiğini araştırmak amacıyla yapıldı̆̆ı ; yöntem olarak çoğunlukla nicel araştırma yöntemlerinin, desen olarak ise deneysel desenlerin kullanıldığı; verilerin ise en çok başarı testleri aracılı̆̆ıyla elde edildiği tespit edilmiştir. Araştırmaların sonuçları incelendiğinde en çok işbirlikli öğrenme yönteminin etkili olduğu, yaşanılan zorluklar incelendiğinde ise en çok çizgi grafiği konusunda zorlanıldığı sonucu elde edilmiştir.

Anahtar Sözcükler

\author{
Veri ișleme \\ Olasilık \\ İstatistik \\ İçerik analizi \\ Makale Hakkında \\ Gönderim Tarihi \\ 28 Kasim 2018 \\ Kabul Tarihi \\ 19 Haziran 2019 \\ Makale Türü \\ Araștırma Makalesi
}

DOI: $10.12984 /$ egeefd.489275

\section{A Content Analysis of the Studies about Data and Probability Learning Areas}

\section{Abstract}

Keywords

This study aims to investigate research trends in the literature on Data Processing and Probability learning areas in the Mathematics Curriculum. To this end, a total of 61 studies performed at elementary school level (5-8th grades) in Turkey, including 34 papers, 24 theses and 3 dissertations were reviewed and subjected to content analysis. To reach relevant studies, the literature was reviewed within the concepts of probability, data processing, graphics and statistical thinking/literacy. The findings were categorized into themes including keywords, methods, designs, sample sizes, instruments, data analysis methods and objectives and results of the research. The data was interpreted based on percentage and frequency, and the findings were presented in tables. Based on the findings obtained, it was determined that most of the studies have been performed to examine the effectiveness of teaching methods suitable of being used in Data and Probability. It was also found that the most commonly used methods are quantitative methods and the most commonly used designs are experimental designs, and that the data have been obtained mostly through achievement tests. When the results of the studies have been examined, it was concluded that the most effective learning method is cooperative learning, and that the biggest challenge is related to line chart.

a processing

Probability

Statistics

Content analysis

Article Info

Received

November 28, 2018

Accepted

June 19, 2019

Article Type

Research Paper

Atıf: Tosun, T. ve Özen Ünal, D. (2019). Veri ve olasılık öğrenme alanlarında yapılmış çalışmaların içerik analizi. Ege Eğitim Dergisi, 20(1), 244-261. doi:10.12984/egeefd.489275

\footnotetext{
* Sorumlu Yazar/Corresponding Author

(1) Adnan Menderes Üniversitesi, Fen Bilimleri Enstitüsü, Türkiye, tubatosunx@gmail.com

2 도 Adnan Menderes Üniversitesi, Eğitim Fakültesi, Matematik ve Fen Bilimleri Eğitimi Bölümü, Türkiye, deniz.ozen@ adu.edu.tr
} 


\section{Extended Abstract}

\section{Introduction}

During the age of innovation, different fields are being developed at a tremendous rate. Education systems are also affected by such development and change. To educate and cultivate individuals who are the type of people that societies need in the improvement process, everyone should be trained for the specific needs. This improvement may only be possible with a well-functioning education system. It can be said that one of the building blocks of an education system is the curriculum (Yenilmez \& Sölpük, 2014). Since developments and changes in education curriculums have been affected in parallel with changes in the field of education, one can conclude that mathematics curriculum changes according to time and certain conditions (Bal, 2008). Mathematics Education Program and curriculums published by the Ministry of National Education of Turkey has seen important changes since 2004 (Baki \& Gökçek, 2005). One learning area that has changed in the mathematics curriculum is the area that includes the topics of probability-statistics. The aim of the fields of Statistics and Probability is summarized overall by Baki (2015), and it is considered to be related to situations in which students are faced with generating research questions, data collecting, data processing, data editing and expressing data by using different forms of representation. Furthermore, students should subsequently interpret and calculate the probabilities of an event by analyzing the situation. In this study, the learning areas of data and probability on an elementary school level (5-8th grades) in Turkey were examined by considering studies and the specific design methods followed, the specific data collection instruments used, the specific data analysis methods employed and the kind of results reached. Therefore, this study can be considered to be useful for identifying the needs of researchers, teachers and curriculum developers as it provides a descriptive analysis of a number of studies in related learning areas in a mathematics curriculum. The aim of this content analysis is to determine comprehensively the studies regarding data and probability in elementary school.

In this context, for this purpose, the following questions guided the current study:

1. What is the distribution of the keywords of the studies on Data and Probability learning areas?

2. What is the distribution of the research methods of the studies investigated?

3. What is the distribution of the research design of the studies investigated?

4. What is the distribution of the sample size of the studies investigated?

5. What is the distribution of the data collection instrument of the studies investigated?

6. What is the distribution of the data analysis method of the studies investigated?

7. What is the distribution of the aims of the studies investigated?

8. What is the distribution of the results of the studies investigated?

\section{Method}

This study was designed in qualitative approach and document analysis is used as the method. Document analysis includes the analysis of related resources and the necessary information about the subjects, facts and events that are to be investigated (Yıldırım \& Şimşek, 2005). The document analysis is thought to be suitable for the purpose of this research as it is a qualitative research method used to analyze existing written materials within a scope of related subjects (Büyüköztürk, Akgün, Karadeniz, Demirel \& Kılıç, 2008).

This study aimed to examine the studies about data and probability. To this end, national papers from Google Scholar and theses from well-known national databases to go over the data and probability studies in the elementary school in Turkey. To gather related studies in the following databases were searched; Dergipark, Google Scholar, ULAKBIM National Databases and YOK National Thesis Centre. The keywords were as follows: probability, data processing and graphics within the framework of statistical thinking and statistical literacy. For the reliability of this research, researchers independently coded all the studies selected for the credibility of the coding. Thus, inter-rater reliability formulated by Miles and Huberman (1994) was found to be 87 .

\section{Findings}

A total of 61 open access studies conducted at elementary school level in Turkey, including 34 papers, 24 theses and 3 dissertations were reviewed and subjected to content analysis. The research findings were divided into themes including keywords, research methods, research designs, sample sizes, data collection instruments, data 
analysis methods and objectives, aims and results of the research. Frequencies of the studies about Data and Probability Learning Areas by means of the codes and themes are presented in this section. According to findings obtained, it was resolved that a major part of studies have been performed so as to inspect the adequacy of showing strategies equipped for being utilized in Data Processing and Probability learning areas. It was also found that the most commonly used research methods are quantitative research methods and the most commonly used designs are experimental designs, and that the data have been obtained mostly through achievement tests. When the results of the studies and the challenges have been examined, it was concluded that the most effective learning method is cooperative learning method, and that the biggest challenge is related to the subject of line chart.

\section{Discussion and Conclusion}

In this study, elementary school level studies conducted in Turkey were examined. To access the studies on data processing and probability learning areas, we had to examine them descriptively and scan national research papers. Dergipark, Google Scholar, ULAKBIM National Database and YÖK National Thesis Center were the databases used to access publications in the literature. The databases revealed a total of 61 full texts, and a content analysis of these texts led to the findings of the study. To explore related studies of the mathematics curriculum regarding data processing and probability learning; statistics, probability, data processing, graphics and statistical thinking, statistical literacy concepts were formed within the scope of the obtained documents. Thus, the findings and evaluations of this study depend more on the findings of the articles analyzed than on the subjective perspectives of the researchers. Most of the studies obtained were papers and only three doctoral dissertations were found. More than half of the studies were designed as quantitative research; the method used the least was the mixed methods design. To investigate the research on data and probability in future studies, it can be recommended that research can be designed with a qualitative research approach or a mixed methods design that will include both qualitative and quantitative research, which will contribute to the literature. 


\section{Giriş}

Bilim ve teknolojinin etkisiyle yaşanan gelişmeler eğitim alanına da yansımaktadır. Toplumların bu süreçte ihtiyaç duyduğu insan tipine uygun bireyler yetiştirilebilmesi ve bireylerin bu ihtiyaçlar doğrultusunda eğitilebilmesi ise ancak iyi işleyen bir eğitim sistemi ile mümkündür. Bu sistemlerin yapitaşlarından birisinin de öğretim programları olduğu düşünüldüğünde (Yenilmez ve Sölpük, 2014) eğitim alanındaki gelişim ve değişimlerinden de en çok öğretim programlarının etkilendiği ve eğitim alanındaki değişimlere paralel olarak zamana ve koşullara göre değiştiği görülmektedir (Bal, 2008). Bu durumu geçmişten bugüne yenilenen ve değişen öğretim programlarına bakarak fark etmek mümkündür.

Matematik Öğretim Programları incelendiğinde; bütün öğretim programlarında olduğu gibi yapılandırmac1 yaklaşımın etkisiyle önemli değişikliklerin yapıldığı görülmektedir (Baki ve Gökçek, 2005). 2013 yılında ise eğitim sisteminde yapılan değişiklikler sonucunda öğretim programlarının yeniden gözden geçirilmesi ve düzenlenmesi ihtiyaç olarak görülmüştür. Bu durumun özellikle matematik öğretim programları üzerindeki yansıması olarak programdaki bazı öğrenme alanları, konular ve kazanımların sınıf seviyeleri ve içerikleri yeniden düzenlenmiş ve çeşitli değişiklikler yapıldığı görülmüştür (Kılıç, Aslan Tutak ve Ertaş, 2014). Matematik öğretim programlarında sınıf düzeyleri ve içerik açısından değişiklik gösteren öğrenme alanlarından biri de Olasılık - İstatistik konularını içeren öğrenme alanıdır. Geçmiş ilköğretim matematik öğretim programına (Milli Eğitim Bakanlığı [MEB], 2005) göre Olasılık öğrenme alanı 5. sınıf dışındaki sınıflarda (6, 7, 8) yer alırken; Veri öğrenme alanı yalnızca 5. sınıfta bulunmaktadır. Bunun yanında, programda 5. sinıfta yer alan Veri öğrenme alanı, diğer sınıf düzeylerinde $(6,7,8)$ İstatistik olarak adlandırılmış ve Olasılık öğrenme alanı ile birleştirilerek olasılık ve istatistik olarak adlandırılmıştır. Bu bağlamda veri veya istatistik öğrenme alanları 2005 programında bütün sınıf düzeylerinde yer almaktadır (MEB, 2005). 2013 matematik öğretim programında (MEB, 2013) ise olasıllk öğrenme alanı sadece 8. sınıfta yer alırken, veri işleme öğrenme alanı bütün sinıf düzeylerinde mevcuttur (MEB, 2013). Önceki programdan (MEB, 2005) farklı olarak, 2013 öğretim programında olasıllk ve istatistik öğrenme alanı revize edilerek, veri işleme ile olasllı olmak üzere iki ayrı öğrenme alanı oluşturulmuştur. 2013 ve 2018 matematik dersi öğretim programları sınıf bazında incelendiğinde ise veri işleme, olasılık öğrenme alanlarının iki programda da değişikliğe uğramadan yer aldığı görülmektedir (MEB, 2013; 2018). Süreç içerisinde değişen matematik programlarında İstatistik öğrenme alanının veri işleme, veri başlıklarıyla da yer aldığı görülse de bu iki temel alan çeşitli kaynaklara göre birlikte düşünülmesi gereken iki temel alandır (Baki, 2015; MEB, 2009).

İstatistik - olasıllk temel alanlarının amacı geniş kapsamda, öğrencilerin karşılaştığı herhangi bir durum ile ilgili, araştırma sorusu üretme, veri toplama, veri işleme, veri düzenleme, verileri farklı temsil biçimleri ile ifade edebilme, yorumlayabilme ve bunun yanında bir olayın olma durumlarını inceleyerek olasılıklarını hesaplayabilme şeklinde özetlenmiş̧tir (Baki, 2015). Benzer şekilde Altun (2008) da ortaokul düzeyi öğrencileri bakımından istatistik alanı ve konularını; bilgileri sistematik olarak toplayabilme, organize etme; elde edilen sonuçları grafiklerle ifade ve analiz edebilme; analiz sonucunda da bilgiyi yorumlama, değerlendirme ve karar verme aşamasında istatistiği kullanabilme olarak yorumlamıştır. Bu konuların öğretiminde önemli amaçlardan biri öğrencileri günlük hayatlarını fazlasıyla etkileyecek olan bu istatistiki bilgilere (Schield, 2010) hazırlamaktır.

İstatistik - Olasılık alanları; başka bir deyişle Matematik Dersi Öğretim Programında (İlkokul ve Ortaokul 1-8. Sinıflar) da belirtildiği şekilde (MEB, 2018) veri işleme ve olasıllk öğrenme alanları, 2009 yılında 1-5. sinıf arasında veri; 6-8. sınıf arasında ise olasllik-istatistik öğrenme alanları altında ele alınmıştır (MEB, 2009). Bunun yanında yine MEB (2013) 5-8 Matematik Öğretim Programında ise veri işleme ve olasıllk öğrenme alanları olarak parçalanarak tüm sınıf düzeylerinde veri işleme öğrenme alanına değinilirken, sadece 8 . Sınıfta olasıllk öğrenme alanından bahsedilmektedir. Öğrenme alanları, sınıf düzeyleri ve konu başlıkları değişiklik gösterse de matematik öğretim programları öğrencilerin bilinçli vatandaş olabilmeleri için veri analizini bilmelerini ve istatistik-olasılık ile ilgili akıl yürütebilmelerini beklemektedir (MEB, 2009; MEB, 2013).

İstatistik - Olasılık alanları 2009'dan günümüze değişikliklere uğramış olmasına rağmen Matematik Dersi Öğretim Programında (MEB, 2018) 1-4. Sınıflar için veri işleme öğrenme alanı veri toplama ve değerlendirme alt öğrenme alanı olarak ilkokulun tüm sınıf seviyelerinde yer almaktadır. Benzer şekilde veri işleme öğrenme alanı; 5-8. Sınıflar için veri toplama ve değerlendirme ve veri analizi alt öğrenme alanları olarak ortaokulun tüm sinıf seviyelerinde (MEB, 2018) ve son olarak yalnızca 8. Sinıf düzeyinde, basit olayların olma olasillğg alt öğrenme alanı ile olasıllk öğrenme alanı yer almaktadır (MEB, 2018).

Ulusal Matematik Öğretmenleri Konseyi'nin [National Council of Teachers of Mathematics (NCTM)] (2000) de öğrencilerden ortaöğretimin sonuna kadar istatistik öğrenme alanı ile ilgili ortak beklentilerini İstatistik Eğitiminde Değerlendirme ve Öğretim Rehberi Raporu'nda (2005) [Guidelines for Assessment and Instruction in Statistics Education (GAISE)] görmek mümkündür. Bunlar; verilere yönelik sorular oluşturma ve sorulara yönelik veri toplama, verileri organize etme ve uygun temsil biçimleri ile gösterme; verilerin analizi için gerekli 
istatistiksel yöntemleri seçebilme; var olan veriler üzerinden tahminlerde bulunarak değerlendirme ve çıkarım yapabilme şeklinde belirtilmiştir. Bu doğrultuda istatistik eğitiminin; verileri grafiğe dökme becerisi gibi dar bir bakış açısından çok, veri toplama, veri analizi gibi önemli becerileri kapsayacak şekilde bir çerçevede ele alındığı söylenebilir (Carnell, 2008; Shaughnessy, Garfield ve Greer, 1996).

Buna paralel şekilde alan yazında (Common Core State Standards Initiative [CCSSI], 2010) veri işleme ve olasılık konularında başarı gösteren bireylerin matematik ile diğer disiplinler arasında veya günlük yaşam arasında daha kolay ilişki kurabildikleri, bu yüzden bu alanların matematiğin en önemli alanları olduğundan bahsedilmiştir (Mokros ve Russell, 1995). Yurt dışındaki matematik programlarında olasıllı ile ilişkilendirilebilecek kavramların orantısal akıl yürütme becerilerini desteklediği düşüncesiyle okul öncesi düzeyden başlamak üzere bütün sınıf düzeylerinde yer alması gerektiği vurgulanmaktadır (NCTM, 2000). Ancak ortaokul matematik öğretim programında (MEB, 2018) sadece 8. sınıfta olasılık öğrenme alanı yer almaktadır. Fen ve Matematik eğitiminin de kritik bir bileşeni olarak görülen veri alanında; verilerin kaydedilmesi, yorumlanması ve temsil edilmesi gibi aktivitelerin bilimde doğru sorgulamalar yapılabilmesi bakımından önem taşıdığı, bu yüzden ders kitaplarında ve öğretim programlarında yer alması gerektiği belirtilmektedir (Morris, Masnick, Baker ve Junglen, 2015). Bu ihtiyaçtan yola çıkılarak gerek ülkemizde gerek diğer ülkelerde matematik öğretim programlarında veri ve olasılık alanlarının önemli bir yere sahip olduğu görülmektedir (CCSSI, 2010; NCTM, 2000; MEB, 2018).

Toplumda istatistiksel becerilere olan ihtiyaç karşısında yenilik arayışına gidilmesiyle beraber bu konuda yapılan çalışmalar artmaktadır. Bu durum, istatistik ve veri kapsamında ele alınan konuların, günlük yaşamda gerekliliği ile birlikte öğretim programlarında yer almasıyla sonuçlanmıştır (NCTM, 2000). Güven, Öztürk ve Özmen (2015) istatistiksel sürecin tam anlamıyla günlük hayatta yaşanması, bu konuda deneyim kazanılması ve yaşanan deneyimler ve zorlukların ortaya koyulması gerektiğini belirtmiştir. Öğrencilerin ilgili öğrenme alanları kapsamında zorlandıkları konular üzerine yapılan çalışmalar alanyazında ele alınmıştır (Çakmak ve Durmuş, 2015; Kaynar ve Halat, 2012; Padilla, McKenzie ve Shaw, 1986; Rubin, Hammerman, ve Konold, 2006; Ulusoy ve Çakıroğlu, 2013). Ayrıca istatistiğin ve temsil biçimlerini anlamlandırma ve anlamlı öğrenmeye katkıda bulunacağına dair çalışmalar (Akkan, Baki ve Çakıroğlu, 2012; Friel, Curcio ve Bright, 2001; Van de Walle, Karp ve Bay-Williams, 2010) ile bu temsil biçimlerinin kavramsal anlamanın yanında problem çözme becerilerinin gelişmesine etkisi açıssından da önemli olduğunun savunulduğu (Schultz ve Waters, 2000) çalışmalar yer almaktadır. Yapılan çalışmalar incelendiğinde araştırma eğilimlerinin belirlenmesine ve araştırmaların içeriğini anlamaya yönelik bir çalışmaya rastlanmamıştır.

$\mathrm{Bu}$ araştırmada; ortaokul düzeyinde veri işleme ve olasıllk öğrenme alanlarına yönelik araştırmaların eğilimlerini incelemek amaçlanmıştır. Bu bağlamda araştırmanın problem cümlesi Veri işleme ve olasıllk ögrenme alanlarına yönelik yapılan araştırmalarda kullanılan anahtar kelimeler, araştırma yöntemleri, araş̧ırma desenleri, veri toplama araçları, veri analiz yöntemleri ve yapılan çalışmaların amaçları ile sonuçları nasıl bir dağıllım göstermektedir? olarak belirlenmiştir. Bu problem cümlesi ile ilgili olarak aşağıdaki sorulara yanıt aranmıştır:

1. Araştırma kapsamındaki çalışmalarda kullanılan anahtar kelimeler nasıl bir dağılım göstermektedir?

2. Araştırma kapsamındaki çalışmalarda kullanılan yöntemler nasıl bir dağılım göstermektedir?

3. Araştırma kapsamındaki çalışmalarda kullanılan desenler nasıl bir dağılım göstermektedir?

4. Araştırma kapsamındaki çalışmalar örneklem büyüklüğü açısından nasıll bir dağılım göstermektedir?

5. Araştırma kapsamındaki çalışmalarda kullanılan veri toplama araçları nasıl bir dağılım göstermektedir?

6. Araştırma kapsamındaki çalışmalarda kullanılan veri analiz yöntemleri nasıl bir dağılım göstermektedir?

7. Araştırma kapsamındaki çalışmaların amaçları nasıl bir dağılım göstermektedir?

8. Araştırma kapsamındaki çalışmaların sonuçları nasıll bir dağılım göstermektedir?

$\mathrm{Bu}$ çalışmada, veri işleme ve olasıllı öğrenme alanlarında ortaokul düzeyinde Türkiye'de yapılan çalışmalar incelenerek, çalışmaların genel olarak hangi yöntemlerle, hangi desenler, hangi veri toplama araçları, hangi veri analiz yöntemleri kullanılarak, hangi amaçlarla ele alındığını ve ne tür sonuçlara ulaşıldığını ortaya koyan bir çalışmadır. $\mathrm{Bu}$ nedenle, araştırmacıların, öğretmenlerin ve program geliştiricilerin matematik öğretim programındaki ilgili öğrenme alanlarındaki çalışmaların içerik analizi ile bu konularda yapılabilecek araştırmalara yönelik ihtiyaçların belirlenmesine faydalı olabileceği düşünülmektedir. 


\section{Yöntem}

\section{Araştırmanın Deseni}

Bu çalışma bir nitel araştırma olarak desenlenmiştir. Bu bağlamda araştırılması hedeflenen konular, olgular ve olaylar hakkında gerekli bilgileri içeren ilgili kaynakların analizini kapsayan nitel araştırmalardan doküman incelemesi (Yıldırım ve Şimşek, 2005) tercih edilmiştir. Araştırmanın amacına uygun olduğu düşünülen doküman inceleme, belgesel tarama olarak belirtilen, ilgili konular kapsamında var olan yazılı materyalleri analiz etmek için kullanılan nitel bir araştırma yöntemidir (Büyüköztürk, Akgün, Karadeniz, Demirel ve Kılıç, 2008).

\section{Veri Toplama Araçları}

Araştırma problemine uygun öğrenme alanlarını ve sınıf düzeyini temel alan 61 çalışma; kullanılan anahtar kelimeler, öğretimde ele alınan teknik, örneklem büyüklüğü, örneklem sınıf düzeyi, araştırma yöntemi, araştırma türü, araştırma deseni, veri toplama aracı, veri analizi yöntemi, araştırmanın amacı ve araştırmanın sonucu kategorilerini içeren dokuz bölümlü bir form altında kodlanmıştır. Araştırmanın veri toplama aracı olan bu formda incelenmek istenen bilgilere yer verilmiştir. Elde edilen çalışmaların sınıflandırılması ve kodlama süreci boyunca güvenirliği artırmak adına kullanılan bu formun geliştirilme sürecinde iki ayrı matematik eğitimi uzmanından görüşleri alınmıştır. Gerekli düzeltmeler yapıldıktan sonra bu form son haline getirilerek araştırmaların sınıflandırılmasında ve incelenmesinde kullanılmıştır. Yapılan kodlamalara ilişkin güvenirlik hesaplamaları Geçerlik Güvenirlik Önlemleri/İnandırıcılık başlığı altında ele alınmıştır.

\section{Veri Toplama Süreci}

Bu çalışmada, Türkiye'de ortaokul düzeyinde yapılan veri işleme ve olasılık öğrenme alanlarına yönelik çalışmalara ulaşmak ve incelemek amacıyla; ulusal veri tabanları taranmıştır. Alan yazındaki yayınlara ulaşmak için taranan; Dergi Park, Google Akademik, ULAKBIM Ulusal Veri Tabanı ve YÖK Ulusal Tez Merkezi veri tabanlarından toplam 61 çalışmaya ulaşılmıştır. İlgili çalışmalara ulaşabilmek için Veri Işsleme ve Olasılık öğrenme alanlarına dair Matematik Dersi Öğretim Programı (İlkokul ve Ortaokul 1, 2, 3, 4, 5, 6, 7 ve 8. Sinıflar) yer alan; olasılık, veri işleme, grafik kavramları ve aynı zamanda istatistik kavramı ile ilişkili kavramlar olan istatistiksel düşünme, istatistiksel okuryazarlık kavramları çerçevesinde tarama yapılmıştır. Tam metinlerine ulaşılabilen bilimsel makaleler ve tez çalışmalarından uygun olanları araştırmanın örneklemini oluşturmaktadır. Ulaşılan çalışmaların yıllara göre dağılımının, 2003-2017 yılları arasında olduğu görülmektedir.

Tablo 1

Araştırma Kapsamındaki Çalışmaların Yayın Yıllarına Göre Dağılımı

\begin{tabular}{lcc}
\hline Y1llar & $f$ & \% \\
\hline 2003-2005 y1lları aras1 & 2 & 3.28 \\
2006-2008 y1lları aras1 & 7 & 11.48 \\
2009-2011 y1lları aras1 & 17 & 27.87 \\
2012-2014 y1lları aras1 & 20 & 32.79 \\
2015-2017 y1lları aras1 & 15 & 24.59 \\
Toplam & 61 & 100 \\
\hline
\end{tabular}

Tablo 1 incelendiğinde 2003-2005 yılları arasında 2 (\% 3.28), 2006-2008 y1lları arasında 7 (\% 11.48), 20092011 yılları arasında 17 (\% 27.87), 2012-2014 yılları arasında 20 (\% 32.79) ve son olarak 2015-2017 y1llar1 arasında 15 (\% 24.59) tane olmak üzere toplam 61 çalışmanın yıllara göre dağılımları ve frekansları görülmektedir.

Tablo 2

Araştırma Kapsamındaki Çalışmaların Yayın Türlerine Göre Dağılımı

\begin{tabular}{lcc}
\hline Tür & $f$ & $\%$ \\
\hline Bilimsel Makale & 34 & 55.74 \\
Yüksek Lisans Tezi & 24 & 39.34 \\
Doktora Tezi & 3 & 4.92 \\
Toplam & 61 & 100 \\
\hline
\end{tabular}

Tablo 2'ye bakıldığında ulaşılan çalışmaların; 34' ünün (\% 55.73) bilimsel makale, 24'ünün (\% 39.34) yüksek lisans ve 3 'ünün (\% 4.91) doktora tezi olduğu görülmektedir. 
Tablo 3

Araştırma Kapsamındaki Çalışmaların Sınıf Düzeyine Göre Dă̆llımı

\begin{tabular}{lcc}
\hline Tür & $f$ & $\%$ \\
\hline 5. Sinıf & 4 & 6.56 \\
6. Sinıf & 5 & 8.20 \\
7. Sinif & 15 & 24.59 \\
8. Sinıf & 24 & 39.34 \\
Ortaokul (5-8.) Siniflar & 13 & 21.31 \\
Toplam & 61 & 100 \\
\hline
\end{tabular}

İncelemeye alınan çalışmalarda, örneklemlerin tamamı gruplanacak olursa 5. Sınıflar düzeyinde 4 (\% 6.56), 6. Sinıflar düzeyinde 5 (\% 8.20), 7. Sinıflar düzeyinde 15 (\% 24.59), 8. Sinıflar düzeyinde 24 (\% 39.34) ve tüm ortaokul (5-8) sınıf düzeylerinde ise 13 (\% 21.31) çalışmaya ulaşılmıştır.

\section{Veri Analizi}

Çalışmanın amacı doğrultusunda elde edilen veriler içerik analizine tabii tutulmuştur. Betimsel içerik analizi; belirlenen konu üzerinde birbirinden bağımsız olarak yapılan nitel ve nicel çalışmaların incelenerek alandaki genel eğilimlerin değerlendirilmesini içeren sistematik çalışmalardır (Çalık ve Sözbilir, 2014). Elde edilen tüm çalışmaların analiz sürecinde bilimsel makalelerin ve tezlerin tam metinleri araştırmacı tarafindan incelenmiş, Matematik öğretim programı veri işleme ve olasıllk öğrenme alanları kapsamında olmayan, başka disiplinleri içeren yayınlar inceleme sürecine dahil edilmemiştir. Bu bağlamda araştırma problemine uygun öğrenme alanlarını ve sınıf düzeyini temel alan, belirli değişkenler açısından incelenmiş 61 çalışma araştırmaya dâhil edilmiştir. Seçilen araştırmalar; kullanılan anahtar kelimeler, öğretimde ele alınan teknik, örneklem büyüklüğü, örneklem sınıf düzeyi, araştırma yöntemine, araştırma türü, araştırma deseni, veri toplama aracı, veri analizi yöntemi, araştırmanın amacı ve araştırmanın sonucu kategorileri altında göre kodlanmıştır. Araş̧ırmanın veri toplama aracı olan bu formda incelenmek istenen bilgilere yer verilmiştir. Elde edilen çalışmaların amaç ve sonuç temaları halinde elde edilen nitel bulgular alt temalar halinde detaylı bir şekilde verilmiş̧ir. Yayın inceleme formundaki çalışmalardan elde edilen kodlar, SPSS 18.0 istatistik paket programı aracılığıyla betimsel analiz edilerek, frekans $(f)$ ve yüzde (\%) dağılımları tablolar halinde sunularak yorumlanmıştır.

\section{Geçerlik Güvenirlik Önlemleri/İnandırıcılık}

Analiz sürecinde incelenen araştırmalar iki matematik eğitimcisi tarafından kodlanmış ve hazırlanan yayın inceleme formunda toplanmıştır. Araştırmanın güvenirliğinin sağlanması için verilerin farklı araştırmacılar ya da aynı araştırmacı tarafindan farklı zamanlarda yapılan analizlerin karşılaştııılması ve aralarındaki benzerlik ilişkilerinin hesaplanması ile yapılabilir (Türnüklü, 2000). Bu araştırmada da, veriler iki araştırmacı tarafindan incelenerek, Kodlayıcılar arası güvenirlik Miles ve Huberman (1994) tarafından önerilen (Görüş Birliği)/(Görüş Birliği + Görüs Ayrılığı) formül ile hesaplanmıştır. Buna göre araştırmanın kodlayıcılar arası güvenirliği .87 bulunmuştur. Kodlayıcılar arası güvenirlik katsayısının .70 'in üzerinde çıkması nedeniyle araştırma güvenilir olarak kabul edilmiştir (Miles ve Huberman, 1994).

\section{Bulgular}

Araştırma kapsamında analizleri yapılan çalışmalar, belirlenen temalar ile alt problemlere göre sıralı bir şekilde tablolar yardımıyla bu bölümde gösterilmiştir.

Öncelikle Araştırma kapsamındaki çalışmalarda kullanılan anahtar kelimeler nasıl bir dağllım göstermektedir? sorusuna yanıt aranmıştır. Bu bağlamda ulaşılan 61 çalışmada kullanılan anahtar kelimelerin dağılımları Tablo 4 'te sunulmuştur.

Tablo 4

Çalışmalarda Kullanılan Anahtar Kelimelerin Dağı̆lımları

\begin{tabular}{lcc}
\hline Tema & $f$ & $\%$ \\
\hline Grafik & 18 & 29.51 \\
Temsil Biçimleri & 2 & 3.28 \\
İstatistik & 7 & 11.48 \\
İstatistiksel Okuryazarlık/Düşünme & 8 & 13.11 \\
Olasilık & 15 & 24.59 \\
Veri & 4 & 6.56 \\
Diğer & 12 & 19.67 \\
Toplam & 61 & 100 \\
\hline
\end{tabular}


Tablo 4 incelendiğinde anahtar kelimelerin yedi farklı temada birleştirildiği görülmektedir. Bunlardan 18 tanesi (\% 29.51) Grafik başlığı altında Matematik Öğretim Programında ilgili kazanımlarda da yer alan daire grafiği, sütun grafiği, çizgi grafiği, grafiksel gösterim, grafik okuma, grafik yorumlama ile ilgili çalışmalar toplanmıştır. 2 çalışmada (\% 3.28) rastlanan temsil biçimleri ise bu grafiklerin gösterimine yönelik çalışmaları ifade etmektedir. Benzer şekilde elde edilen 8 çalışmanın ise (\% 13.11) istatistiksel süreçler ile ilgili olduğu; istatistiksel okuryazarlık ve istatistiksel düşünmeye yönelik olduğu görülmektedir. İstatistiksel süreçten farklı olarak sadece istatistik ile ilgili olan 7 çalışma (\% 11.48) araştırma kapsamında incelenmiştir. Bunun yanında 4 çalışmada ise (\% 6.56) Veri başlığı kapsamında aynı şekilde programda yer alan Veri İşleme, Veri Toplama ve Değerlendirme ile ilgili yapılan çalışmalar yer almaktadır. Diğer teması altında incelenen 12 çalışma (\% 19.67) ise konularla ilgili temel kavramlar ve anahtar kelimeler ile taramalar yapılarak ulaşılan, fakat anahtar kelimeler olarak araştırılması hedeflenen konu ile ilgili bir kavram belirtilmeyen araştırmaları kapsamaktadır. Diğer başlığ altında öğretim yöntemi etkililiğinin incelenmesi ve duyuşsal özelliklerin incelenmesi amacıyla incelenen bazı çalışmaların olduğu görülmektedir. Bu çalışmalarda anahtar kelimeler; işbirlikli öğrenme yöntemi, tutum, motivasyon, matematik öğretimi, akademik başarı, kalıcılık düzeyi, matematik başarısı vb. olarak belirtilmiştir. Konuyla ilgili olan bu çalışmalar araştırmacılar tarafından Diğer teması altında ele alınmıştır.

Araştırma kapsamında ulaşılan çalışmalarda kullanılan yöntemlere yönelik frekans ve yüzde dağılımı Tablo 5 'te sunulmuştur.

Tablo 5

Araştırma Kapsamındaki Çalı̧̧maların Yöntemlerine Göre Dağılımı

\begin{tabular}{lcc}
\hline Yöntem & $f$ & \% \\
\hline Nicel & 36 & 60.55 \\
Nitel & 18 & 27.86 \\
Nitel+Nicel & 4 & 6.55 \\
Karma & 3 & 4.91 \\
\hline
\end{tabular}

İncelenen çalışmalar araştırma yöntemine göre; 36’sı (\% 60.65) nicel yöntem, 18'i (\% 27.86) nitel yöntem, 3’ü (\% 4.91) karma yöntem olarak nitelendirilmemiş olan hem nitel hem nicel yöntem ve 4'ü (\% 6.55) karma yöntem olmak üzere dört grupta incelenmiştir.

Tablo 6'ya göre yapılan çalışmaların birçoğu (\% 44.26) deneysel desenlerde gerçekleştirildiği, bir kısmında ise betimsel desenlerin (\% 37.69) tercih edildiği söylenebilir. Betimsel desende yapılan çalışmalar da kendi içerisinde sınıflandığında ise 11 çalışmanın (\% 18.03) durum çalışması olarak desenlendiği görülmektedir. Yapılan araştırmaların dört tanesinde (\% 6.56) ise araştırmanın deseni belirtilmemiştir, yine bu durumda Tablo 6'da belirtilmiştir.

Tablo 6

Araştırma Kapsamındaki Çalışmaların Desenlerinin Dağılımı

\begin{tabular}{llcc}
\hline Araştırma Deseni & & $f$ & $\%$ \\
\hline Betimsel & Durum & 11 & 18.03 \\
& Doküman İnceleme & 2 & 3.28 \\
& Diğer & 10 & 16.39 \\
Deneysel & & 27 & 44.26 \\
Gelişimci Araştırma & & 2 & 3.28 \\
Açıklayic1/Karma & & 3 & 4.92 \\
Korelasyonel & & 2 & 3.28 \\
Belirtilmemiş & & 4 & 6.56 \\
Toplam & 61 & 100 \\
\hline
\end{tabular}

Araştırma kapsamında ulaşılan çalışmalar örneklem büyüklüğü bakımından belirli aralıklar altında gruplandırılarak elde edilen veriler Tablo 7'de sunulmuştur. Buna göre elde edilen çalışmaların örneklem büyüklüğü açısından dağılımı ise; 0-50 katılımcıyla yürütülen 11 (\% 18.03), 50-100 katılımcıyla yürütülen 27 (\% 44.26), 100-150 katılımciyla yürütülen 5 (\% 8.20) ve 150'den fazla katılımciyla yürütülen 16 (\% 26.23) çalışmaya rastlanmaktadır. Yürütülen çalışmalarda araştırmalara dahil olan kişi sayısının 50-100 kişiyi belirten aralıkta yoğunlaştığg görülmektedir. Veri toplama araçlarına yönelik dağılım Tablo 8'de sunulmuştur. 
Tablo 7

Araştırma Kapsamındaki Çalışmaların Örneklem Büyüklüğ̈̈ Dă̆glımı

\begin{tabular}{lcc}
\hline Örneklem Büyüklüğ̈̈ & $f$ & $\%$ \\
\hline $0-50$ & 11 & 18.03 \\
$50-100$ & 27 & 44.26 \\
$100-150$ & 5 & 8.20 \\
$150+$ & 12 & 19.67 \\
Toplam & 61 & 100 \\
\hline
\end{tabular}

Tablo 8'e göre veri toplama araçları yedi farklı başlık altında ifade edilmiştir. Bu tabloda, bir çalışmada birden çok ölçme aracı kullanıldığı durumlar olduğu için toplam ölçme aracı frekansı ve yüzdesi belirtilmemiştir. Buna göre yapılan çalışmalarda veri toplama aracı olarak 40’ında (\% 65.57) başarı testleri, bilgi testleri, gelişim testleri gibi testlerin, 12'sinde (\% 19.67) görüşme formlarının; 15'inde (\% 24.59) ise alan ölçeklerinin kullanıldığı görülmektedir. Açık uçlu sorular ve etkinlikler ile veri toplanan çalışma sayısı 13 (\% 21.31) iken; anket-form ve gözlem aracılığıyla veri toplanan her birinde 7 adet (\% 11.47) çalışma bulunmaktadır. Son olarak, doküman inceleme yöntemi ile veri toplanan 6 (\% 9.84) çalışmaya rastlanmıştır.

Tablo 8

Araştırma Kapsamındaki Çalışmaların Kullanılan Veri Toplama Araçları Dağılımı

\begin{tabular}{lcc}
\hline Veri Toplama Araçları & $f$ & $\%$ \\
\hline Test & 40 & 65.57 \\
Görüşme & 12 & 19.67 \\
Ölçek & 15 & 24.59 \\
Açı Uçlu Soru-Etkinlik & 13 & 21.31 \\
Anket-Form & 7 & 11.47 \\
Gözlem & 7 & 11.47 \\
Doküman İnceleme & 6 & 9.84 \\
\hline
\end{tabular}

Elde edilen çalışmaların veri analiz yöntemlerine göre dağılımları Tablo 9'da sunulmuştur.

Tablo 9

Araştırma Kapsamındaki Çalışmaların Verilerin Analiz Yöntemleri Dă̆ılımı

\begin{tabular}{lcc}
\hline Veri Analiz Yöntemi & $f$ & $\%$ \\
\hline Betimsel & 18 & 29.51 \\
İstatistiksel & 42 & 68.85 \\
İçerik Analizi & 4 & 6.55 \\
\hline
\end{tabular}

Tablo 9'a göre, veri analiz yöntemleri dağılımı üç farklı başlık altında ifade edilmiştir. Bazı araştırmalarda birden çok veri analizi yöntemi kullanıldığ için frekans $(f)$ ve yüzde $(\%)$ toplamları bu tabloda belirtilmemiştir. Yapılan bu çalışmaların 18 tanesinde (\% 29.51) betimsel yöntemler kullanıldığı, 42'sinde (\% 68.85) istatistiksel yöntemler kullanıldığı ve 4'ünde (\% 6.55) içerik analizi kullanıldığı ifade edilmiştir. Bunun yanında istatistiksel analiz yapılan çalışmalarda t-testi, ANOVA, Mann Whitney U, MANCOVA analizlerinin de kullanıldığı Tablo 9'a ek olarak belirtilebilir.

Elde edilen çalışmaların amaçlarına yönelik bulgular Tablo 10’da sunulmuştur.

Tablo 10

Araştırma Kapsamındaki Çalışmaların Amaçlarına Yönelik Dağılımı

\begin{tabular}{lcc}
\hline Amaç & $f$ & $\%$ \\
\hline Yöntem Etkililiğ̈i & 35 & 55.77 \\
Kavram Bilgisi İnceleme & 21 & 34.42 \\
Bilgi-Beceri İnceleme & 6 & 9.83 \\
Duyuşsal Özellikler & 14 & 22.95 \\
Çizim Becerisi İnceleme & 4 & 6.55 \\
Diğer & 7 & 11.47 \\
\hline
\end{tabular}

Tablo 10'da analiz edilen çalışmaların amaçlarına yönelik bulguları altı ayrı başlık altında ele alınmıştır. İncelenen çalışmaların 35 tanesinde (\% 55.77) yöntem etkililiğinin incelendiği görülmektedir. Burada yöntem etkililiği ile ortaokul düzeyi öğrencilere ilgili konularda uygulanan çalışma yaprakları, materyaller, kavram haritaları ya da geleneksel öğretimden farklı öğretim teknikleri ve farklı öğretim araçları kastedilmektedir. Ele alınan çalışmaların 21 tanesinde (\% 34.42) kavram bilgisi inceleme amacına yönelik bir araştırma yapıldığı 
görülmektedir. Kavram bilgisi inceleme ise olasılık, istatistik, grafik gibi temel kavramlar üzerine yapılan araştırmaları temsil etmektedir. Çalışmaların 6 tanesi (\% 9.83) bilgi-beceri inceleme amacı altında ele alınmıştır. duyuşsal özellikler kapsamında incelenen 14 çalışmada (\% 22.95) ise tutum, motivasyon, kaygı gibi duyuşsal özellikler vurgulanmaktadır. Çizim becerisi inceleme ile ele alınan 4 çalışmada (\% 6.55) öğrencilerin veriler ile grafik, tablo, histogram çizebilmelerine yönelik yürütülen araştırmaları kapsarken, diğer başlığı altındaki 7 çalışma (\% 11.47) ise doküman incelemesi, ölçme aracı geliştirme gibi çalışmaları kapsamaktadır. Bazı çalışmalarda birden fazla amaca hitap edildiği için, aynı çalışmanın iki tema altına dahil edildiği durumlar dolayısıyla frekans ve yüzde ile ilgili toplam belirtilmemiştir. Elde edilen çalışmaların sonuçlarına yönelik bulgular Tablo 11'de sunulmuştur.

Tablo 11 incelendiğinde elde edilen çalışmaların sonuçlarına yönelik bulgular beş ayrı başlık altında ele alınmıştır. Tablo 11 'e göre yöntem etkililiği alt temasında yapılan toplam 20 çalışmada çalışmalarda en çok (\% 9.83) işbirlikli öğrenmeye başvurulduğu görülmektedir. Bunun yanında diğer başlığı kapsamında incelenen 4 çalışmada (\% 6.55) ise proje tabanlı ögrenme, etkinlik temelli ögrenme, graf teori, probleme dayalı öğrenme, argümantasyon yoluyla ögrenme, sinav yoluyla ögrrenme, aktif ögrrenme ve çoklu zeka kuramına göre ögrrenme teknikleri ile yapılan çalışmalar incelenmiştir. Yaşanılan zorluklar alt temasındaki toplam 25 çalışmaya (\% 40.93) bakıldığında ise ortaokul düzeyi öğrencilerin en çok çizgi grafiği konusunda zorluk yaşadıkları görülmektedir.

Tablo 11

Araştırma Kapsamındaki Çalışmaların Sonuçlarına Yönelik Dağılımı

\begin{tabular}{lccc}
\hline Tema & Araştırma Alanı & $f$ & $\%$ \\
\hline Yöntemin Etkililiği & İşbirlikli Öğrenme & 6 & 9.83 \\
& Bilgisayar Destekli & 5 & 8.19 \\
& Yaratıcı Drama (Dramatizasyon, & 2 & 3.27 \\
& Canlandırma) & 6.55 \\
& Gerçekçi Matematik & 4 & 4.91 \\
Sinıf Düzeylerine Göre & Diğer & 3 & 13.11 \\
Farklılıklar & --- & 8 & 4.91 \\
& Histogram & 3 & 16.39 \\
& Çizgi Grafiği & 1.63 \\
Yaşanılan Zorluklar & Siklik Tablosu & 3.27 \\
& Daire Grafiği & 1 & 6.55 \\
& Sütun Grafiği & 2 & 1.63 \\
Kavram Öğrenimi & Veri Toplama-Analiz- & 4 & 6.55 \\
Dĭğer & Yorumlama & 1 & 9.83 \\
\hline
\end{tabular}

\section{Sonuç ve Tartışma}

Bu araştırmada Türkiye'de ortaokul düzeyi veri işleme ve olasılık konularında yapılan çalışma eğilimleri elde edilen bulgular doğrultusunda tartışılmıştır.

Araştırmanın literatür tarama sürecinde Türkiye'de yapılan ortaokul düzeyindeki veri işleme ve olasılık öğrenme alanlarına yönelik çalışmalara yıllar bazında bir sınırlama getirilmemesine rağmen edilen çalışmaların 20032017 yılları arasında olduğu görülmektedir. Çalışmaların dağılımları incelendiğinde yıllar geçtikçe bu konuda yapılan çalışmalarda sayısal bir artış olduğu görülmektedir. Burada araştırmaların, yarısından fazlasının 2012 yılından sonra yapılmasının, veri işleme ve olasılık konularına 2012 yılından itibaren bir yönelim olmasından kaynaklandığı düşünülebilir. Bu öğrenme alanları; 2009 matematik öğretim programında 1-5 sınıf düzeyinde veri öğrenme alanı olarak, 6-8 sınıf düzeyinde istatistik ve olasılık öğrenme alanı olarak bir arada ele alınmıştır (MEB, 2009). 2013 programından itibaren ise veri işleme tüm sınıf düzeylerinde ayrı ayrı, olasılık öğrenme alanı ise sadece 8. Sınıf düzeyinde ele alınmıştır (MEB, 2013). Dolayısıyla 2013 yılından itibaren öğretim programlarında ilgili öğrenme alanlarının ayrı ayrı ele alınmasının, 2012 yılı itibariyle bu alanlarda yapılan çalışmaların artmasına neden olduğu söylenebilir.

Ayrıca veri işleme ve olasılık öğrenme alanlarından; veri işleme öğrenme alanına yönelik çalışmaların, olasılık öğrenme alanına göre daha az sayıda olduğu saptanmıştır. Benzer şekilde Yanık, Özdemir ve Eryılmaz Çevirgen (2017) de özellikle veri işleme öğrenme alanını ele alan sınırlı sayıda çalışma olduğunu ve bu çalışmalarında çoğu zaman ilgili öğrenme alanına dolaylı olarak değindiklerini vurgulamıştır. Oysa Matematik öğretim programlarının her kademesinde yer alan veri konusuna ilişkin öğrenme alanının matematik, fen bilimleri, sosyal 
bilimler gibi disiplinler için önemli bileşenlerden biri olduğu söylenebilir. Bu bağlamda literatürde de verileri analiz etmenin, veri toplama ve değerlendirmenin, verileri yorumlamanın, çıkarım yapabilmenin ve tahminlerde bulunmanın önemi vurgulanmıştır (Ertem, 2007; Koparan ve Güven, 2013). Bu nedenle yapılan çalışmaların arttırılmasının literatüre önemli ölçüde katkısının olacağı düşünülmektedir. Araştırma kapsamında incelenen çalışmaların büyük bir kısmının bilimsel makale türünde olduğu görülmüş, lisansüstü doktora tezi türünde ise sadece üç çalışmaya erişilmiştir. Bu sonuç doğrultusunda lisansüstü eğitim alan öğrenciler, son yıllarda öneminin artan bu konularla ilgili olarak yapılacak çalışmaların çoğalması açısından teşvik edilebilir.

Ele alınan çalışmaların yarısından fazlası nicel araştırma olmakla birlikte, nitel desenlenen çalışmalar nicel araştırmalara kıyasla daha az sayıda yapılmıștır. Ayrıca araştırmalarda en az kullanılan yöntemin de karma yöntem olduğu görülmektedir. Bu çalışmalarda nicel yöntemin sıklıkla kullanılmasının sebebi olarak; bu yöntemin araştırma sonuçlarını genelleyebilme, geniş örneklemlere ulaşabilme ve zaman açısından sağladığı kolaylıklar gösterilebilir (Göktaş ve diğ., 2012). Nitel araştırmaların nicel araştırmalara göre daha az tercih edilmesi literatürde nitel araştırmaların daha fazla zaman alması, alanda yetkinlik gerektirmesi, örneklem seçiminden kaynaklanan vb. farklı iş yükleri getirmesi gibi sebeplerle açıklanmaktadır (Arık ve Türkmen, 2009; Bağ ve Çalık, 2017; Ozan ve Köse; 2014). Araştırma deseni olarak karma yöntem kullanılan çalışmalara az rastlanması ise bu desenin farklı ölçme araçlarını kullanmayı gerektirmesi ve birlikte gerektirdiği iş yükü dolayısıyla fazla tercih edilmemesinden kaynaklanabilir (Bağ ve Çalık, 2017; Doğan ve Tok; 2018). Gelecek çalışmalarda veri öğrenme alanına yönelik konuların, derinlemesine incelenmesi amacıyla, nitel araştırma ya da karma yöntem araştırması olarak desenlenmesinin alan yazına katkısı olacağı söylenebilir. Özellikle karma yöntem araştırılmalarının alanyazına kazandırılması, birden fazla veri toplama tekniğinin kullanılması boyutuyla araştırma sonuçlarının geçerlik ve güvenirliklerinin arttırılmasına da katkıda bulunabilir (Sözbilir ve Kutu, 2008).

Araştırmaların örneklem türü incelendiğinde ise ortaokul düzeyinde en çok 8. Sınıf öğrencilerinin katılımı ile çalışmalar yapıldığı görülmektedir. $\mathrm{Bu}$ durum kazanımlarla ilişkilendirildiğinde, öğrencilerin 8. Sınıfa geldiklerinde üç veri grubunu içeren çizgi ve sütun grafiklerini yorumlayabilmeleri ve araştırma sorularına ilişkin verileri uygunluğuna göre sütun, daire ve çizgi grafiği ile gösterebilmeleri ve bu gösterimler arasında uygun olan dönüşümleri yapabilmeleri açısından yetkinliğe ulaşmış olmalarıyla açıklanabilir. Özelde ortaokulun diğer sınıf düzeylerinde de ilgili öğrenme alanlarına ilişkin kazanımlar yer alsa da 8. Sınıflarda bu kazanımların tamamının öğrenilmiş olması ve yapılan çalışmaların kazanımlar açısından içeriğin zengin olması örneklem türü açısından en çok 8. Sınıf öğrencileriyle çalışılmış olmasına sebep olabilir.

Yapılan araştırmaların büyük bir çoğunluğu deneysel desen, daha az bir kısmı ise betimsel desenlerden durum çalışması olarak gerçekleştirilmiştir. Yapılan çalışmaların amaçlarına göre incelendiğinde, birçoğunun araştırmalarda kullanılan öğretim yöntem ve tekniklerinin etkililiğinin incelenmesine dayalı olduğu görülmektedir. Bu durumda matematik öğretiminde geleneksel öğretim yöntemlerine alternatif olarak işbirlikli öğrenme, bilgisayar destekli öğretim gibi yöntemlerin etkililiğinin test edilmesine yönelik eğilim olduğu söylenebilir. Bu durumunda Türkiye'de 2005 yılı itibariyle ilköğretim ve ortaöğretim programlarında (MEB, 2005; MEB, 2018) yapılandırmacılık, çoklu zeka, bilgi iletişim teknolojileri kullanımı ve işbirlikli öğrenme gibi konuların öneminin artışıyla araştırmacıların bu tür müdahalelerin nasıl etkileri olduğunu belirleme isteğinden kaynaklandığı düşünülebilir.

Elde edilen çalışmalarda kullanılan anahtar kelimelerin yedi ayrı başlıkta toplandığı görülmektedir. Bu çalışmalarda kullanılan anahtar kelimelere bakıldığında yapılan çalışmaların en çok grafik başlığı altında, ikinci olarak ise olasılık başlığı altında toplandığı görülmüştür. Grafikler ile ilgili yapılan çalışmaların olasılık konusuna göre daha fazla oluşunun sebebinin ortaokul matematik ögretim programlarındaki grafikler ile ilgili kazanımların, olasılık ile ilgili kazanımlardan daha fazla oluşu ve içerik açısından çeşitlenmesinden (MEB, 2009; MEB, 2013; MEB, 2018) kaynaklandığı düşünülebilir. Öte yandan diğer teması altında incelenen çalışmaların ise veri ve olasılık konuları ile ilgili olmalarına rağmen matematik öğretim programlarında yer alan ilgili öğrenme alanları altındaki terimler ve kavramlardan (MEB, 2018) herhangi birini içermedikleri görülmüştür. Bu durumun sebebi yapılan araştırmalarda, matematik eğitiminde kullanılabilecek bir öğretim yöntemi, duyuşsal beceriler, başarı durumu gibi değişkenlerin öne çıkarılmasından kaynaklandığı düşünülmektedir. Çalışmalarda kullanılan veri toplama araçları incelendiğinde çalışmaların büyük bir çoğunluğunda ölçme aracı olarak başarı testleri, yeterlik testleri gibi testlerin kullanıldığı görülmüştür. Bu durumun nicel desenlenmiş deneysel çalışmalarda başarı testlerinin diğer ölçme araçlarına kıyasla uygulanmasının tercih edilmesine ve kısa zamanda çok sayıda veri toplamaya imkân vermesinden kaynaklandığ söylenebilir (Bağ ve Çalık, 2017; Şimşek ve diğ. 2009).

İlgili çalışmalarda istatistiksel yöntemlerin betimsel yöntemlerine göre daha fazla kullanıldığı görülmektedir. Bu durumun elde edilen çalışmaların daha çok nicel araştırmaya göre desenlenmesinden kaynaklandı̆̆ düşünülebilir. Literatür incelendiğinde bu durumu destekleyen çalışmalar mevcuttur (Arık ve Türkmen, 2009; Karadağ, 2009; Fazlığulları ve Kurul, 2012; Hranstinski ve Keller, 2007). 
Yapılan araştırmaların amaçları ele alındığında en çok kullanılan öğretim yöntem etkililiğinin araştırıldığı benzer şekilde sonuçlarda da aynı temanın ele alınması üzerine işbirlikli öğrenme ve bilgisayar destekli öğretim ile ilgili konularda çalışmalara rastlandığı görülmektedir. Benzer şekilde Tatar, Kağızmanlı ve Akkaya'nın (2013) da bilgisayar destekli öğretimin daha fazla kullanılması sonucuna ulaşmıştır. Bu bağlamda ilgili konularda planlanacak çalışmalara bilgisayar destekli öğretim entegre edilebilir veya geleneksel öğretimin yanında kullanılabilecek öğretim yaklaşımlarının, materyallerin öğretim sürecine olumlu katkı sağlayabileceği söylenebilir. Benzer şekilde yine amaçlar arasında kavram bilgisi inceleme başlı̆̆ı altında ele alınan çalışmalarında çoğunlukta olduğu görülmektedir. Bu başlık altında istatistik-olasılık alanları ile ilgili temel kavramlar konusunda öğrencilerin mevcut bilgilerini (Çakmak ve Durmuş, 2015) ve yeterliklerini inceleyen (Koparan ve Güven,2014) çalışmalar ele alınmıștır. Kavram bilgisi inceleme amacına benzer bir içerikle sonuçlarda ele alınan kavram ögrenimi üzerine de çalışmalara (Hayat, 2009; Çakmak, 2014) ulaşılmıştır. Araştırmaların sonuçları ele alındığında yaşanılan zorluklar başlığı altında en çok çizgi grafiği konusuna dair zorluklar yaşandığı saptanmıştır. Ayrıca öğrencilerin sütun ve daire grafiklerinde de birtakım zorluklar yaşadıkları, hata ve kavram yanılgılarına sahip olduğu sonucu elde edilmiştir. Literatür incelendiğinde de gerek çizgi grafiğginde yaşanan zorluklar (Gürakar, 2010; Selamet, 2014; Sezgin-Memnun, 2013) gerekse sütun ve daire grafiklerinde yaşanan zorluklar ve kavram yanılgıları (Tortop, 2011; Turhan, 2015) çeşitli araştırmalarda vurgulanmıştır.

Araştırma sonucunda veri ve olasıllk öğrenme alanlarının öğretiminin nasıl olması gerektiğine dair nitel ve derinlemesine çalışmalar yapılmasına ihtiyaç olduğu görülmektedir. Gerek araştırmacılar gerekse alanın uygulayıcısı olan öğretmenler veri, olasılık ve ilişkili diğer kavramların öğretiminde yaşanan zorluklara vurgu yapmaktadır (Batanero, Serrano ve Garfield, 1996; Ficshbein ve Schnarch, 1997; Hacisalihoğlu-Karadeniz, 2016; Kutluca ve Baki, 2009; Shaugnessy, 1992). Dolayısıyla alanın öğretimine yönelik tasarım araştırması ve öğretim deneyi çalışmalarının yapılması ve yaygınlaştııılması araştırmacılara ve uygulayıcılara ışı tutacaktır.

$\mathrm{Bu}$ araştırmada veri ve olasllı öğrenme alanlarında temel kavramlar olarak ele alınabilecek Matematik dersi Öğretim Programında yer alan; olasılık, veri işleme, grafik kavramları ve aynı zamanda istatistik kavramı ile ilişkili kavramlar olan istatistiksel düşünme, istatistiksel okuryazarlık kavramları üzerinden tarama yapılarak, ilgili konulardaki araştırma eğilimleri belirlenmeye çalışılımıştır. Sonuç olarak veri ve olasıllk alanları ile ilgili ulusal literatürde yer alan çalışmaların nasıl çeşitlendiği incelenmiştir. Elde edilen sonuçlara dayanarak araştırmacılara giderek önemi artan bu öğrenme alanlarında nitel ve karma desen çalışmalar yapmaları, lisansüstü çalışmalar için bu alanda öğrenim gören öğrencilerini teşvik etmeleri ve bu alanın öğretimine ilişkin çalışmalar yoluyla uygulayıcı ve öğretmenlere öncülük etmeleri önerilebilir. 


\section{Kaynakça/References}

Akkan, Y., Baki, A. ve Çakıroğlu, Ü. (2012). 5-8. sınıf öğrencilerinin aritmetikten cebire geçiş süreçlerinin problem çözme bağlamında incelenmesi. Hacettepe Üniversitesi Eğitim Fakültesi Dergisi, 43, 1-13.

Altun, M. (2008) . Illkögretim İkinci Kademe (6, 7 ve 8. Sinıflarda) Matematik Öğretimi. Bursa: Erkam Matbaacilık.

Arık, R. S. ve Türkmen, M. (2009, Mayıs). Eğitim Bilimleri Alanında Yayımlanan Bilimsel Dergilerde Yer Alan Makalelerin Incelenmesi. I. Uluslararası Türkiye Eğitim Araştırmaları Kongresi, Çanakkale On Sekiz Mart Üniversitesi, Çanakkale.

Bağ, H. ve Çalık, M. (2017). İlköğretim düzeyinde yapılan argümantasyon çalışmalarına yönelik tematik içerik analizi. Eğitim ve Bilim, 42(190), 281-303. doi:10.15390/EB.2017.6845

Baki, A. (2015). Kuramdan Uygulamaya Matematik Eğitimi (6. Baskı). Ankara: Harf Eğitim Yayıncılık.

Baki, A. ve Gökçek, T. (2005). Comparison of the development of elementary mathematics curriculum studies in Turkey and U.S.A. Educational Sciences: Theory \& Practice, 5(2), 579-588.

Bal, P. (2008). Yeni ilköğretim matematik öğretim programının öğretmen görüşleri açısından değerlendirilmesi. Çukurova Üniversitesi Sosyal Bilimler Enstitüsü Dergisi, 17(1), 53-68.

Batanero, C., Serrano, L. \& Garfield, J. B. (1996). Heuristics and biases in secondary school a students' reasoning about probability. Proceedings of the Conference of the International Group for the Psychology of Mathematics Education, 20th, Valencia, Spain.

Büyüköztürk, Ş., Akgün, Ö. E., Karadeniz, Ş., Demirel, F. ve Kılıç, E. (2008). Bilimsel Araştırma Yöntemleri. Ankara: Pegem A Yayıncılık.

Carnell, L. J. (2008). The effect of a student-designed data collection project on attitudes towards statistics. Journal of Statistics Education, 16(1). doi: 10.1080/10691898.2008.11889551.

Common Core State Standards Initiative (CCSSI) (2010). Common Core State Standards for Mathematics. Washington, DC: National Governors Association Center for Best Practices and the Council of Chief State School Officers.

Çakmak, Z. T. ve Durmuş, S. (2015). İlköğretim 6-8. sınıf öğrencilerinin istatistik ve olasılık öğrenme alanında zorlandıkları kavram ve konuların belirlenmesi. Abant İzzet Baysal Üniversitesi Eğitim Fakültesi Dergisi, 15(2), 27-58.

Çalık, M. ve Sözbilir, M. (2014). İçerik analizinin parametreleri. Eğitim ve Bilim, 39(174), 33-38. doi:10.15390/EB.2014.3412

Doğan, H. ve Tok, T. N. (2018). Türkiye'de Eğitim Bilimleri Alanında Yayınlanan Makalelerin İncelenmesi: Eğitim ve Bilim Dergisi Örneği. Current Research in Education, 4(2), 94-109.

Fazlığulları, O. ve Kurul, N. (2012). Türkiye'deki Eğitim Bilimleri Doktora Tezlerinin Karakteristikleri. Mehmet Akif Ersoy Üniversitesi Eğitim Fakültesi Dergisi, 1(24), 43-75.

Fischbein, E. \& Schnarch, D. (1997). The evolution with age of probabilistic, intuitively based misconceptions. Journal For Research in Mathematics Education, 28, 96-105. doi:10.2307/749665

Friel, S. N., Curcio, F. R., \& Bright, G. W. (2001). Making sense of graphs: Critical factors influencing comprehension and instructional implications. Journal For Research in Mathematics Education, 32(2), 124-158. doi: $10.2307 / 749671$

GAISE (2005). Guidelines for assessment and instruction in statistics education (GAISE) report: A curriculum framework for PreK-12 statistics education. The American Statistical Association (ASA).

Göktaş, Y., Arpacık, Ö., Yıldırım, G., Aydemir, M., Küçük, S., Telli, E. ve Reisoğlu, İ. (2012). Türkiye'de eğitim teknolojileri araştırmalarındaki eğilimler: 2000-2009 dönemi makalelerinin içerik analizi. Kuram ve Uygulamada Ĕgitim Bilimleri, 12(1), 177-199.

Hacısalihoğlu-Karadeniz, M. (2016). Beşinci sınıf öğrencilerinin veri işleme konusundaki kazanımlara ulaşabilme durumlarının belirlenmesi. Akdeniz Insani Bilimler Dergisi, 4(1), 221-236. doi:10.13114/MJH.2016119300 
Hrastinski, S. \& Keller, C. (2007). An examination of research approaches that underlie research on educational technology: a review from 2000 to 2004. Journal of Educational Computing Research, 36(2), 1-22. doi:10.2190/H16L-4662-6000-0446

Jones, G. A., Thornton, C. A., Langrall, C. W., Mooney, E. S., Perry, B. \& Putt, I. J. (2000). A Framework for Characterizing Children's Statistical Thinking, Mathematical Thinking and Learning, 2(4), 269-307. doi:10.1207/S15327833MTL0204_3

Kaynar, Y. ve Halat, E. (2012, Haziran). Sekizinci sınıf öğrencilerinin sıklık tablosu okuma ve yorumlama becerilerinin incelenmesi. X. Ulusal Fen Bilimleri ve Matematik Eğitimi Kongresi, Niğde.

Kılıç, H., Aslan-Tutak, F. ve Ertaş, G. (2014). TIMSS merceğiyle ortaokul matematik öğretim programındaki değişiklikler. Mersin Üniversitesi Eğitim Fakültesi Dergisi, 10(2), 129-141.

Koparan, T. ve Güven, B. (2013). İstatistik öğretiminde yeni yaklaşımların istatistiksel okuryazarlığa etkisi: Proje tabanlı öğrenme. Ĕgitim ve Öğretim Araştırmaları Dergisi, 3(4), 356-377.

Kutluca, T. ve Baki, A. (2009). 10. sınıf matematik dersinde zorlanılan konular hakkında öğrencilerin, öğretmen adaylarının ve öğretmenlerin görüşlerinin incelenmesi. Kastamonu Üniversitesi Kastamonu Ĕ̆itim Dergisi, $17(2), 616-632$.

Miles, M. B. \& Huberman, A. M. (1994). Qualitative data analysis: An expanded sourcebook. Sage.

Milli Eğitim Bakanlığı (MEB) Talim Terbiye Kurulu Başkanlığı (2005). İlköğretim matematik dersi (6-8. sinıflar) ögretim programı. Ankara: Devlet Kitapları Müdürlüğü Basımevi.

Milli Eğitim Bakanlığı (MEB) Talim ve Terbiye Kurulu Başkanlığı (2009). İlköğretim Matematik 6-8. Sınıflar Öğretim Programı. Ankara.

Milli Eğitim Bakanlı̆̆ı (MEB) (2013). Ortaokul matematik dersi (5, 6, 7 ve 8. Sinıflar) ögretim programı. Ankara: Devlet Kitapları Müdürlüğü Basımevi.

Milli Eğitim Bakanlığı (MEB) (2018). Matematik dersi öğretim programı (ilkokul ve ortaokul 1, 2, 3, 4, 5, 6, 7 ve 8. sinıflar). Ankara.

Mokros, J. \& Russell, S. (1995). Children's concepts of average and representativeness. Journal for Research in Mathematics Education, 26(1), 20-39. doi:10.2307/749226

Morris, B. J., Masnick, A. M., Baker, K., \& Junglen, A. (2015). An analysis of data activities and instructional supports in middle school science textbooks. International Journal of Science Education, 37(16), 27082720. doi:10.1080/09500693.2015.1101655

Ozan, C. ve Köse, E. (2014). Eğitim programları ve öğretim alanındaki araştırma eğilimleri. Sakarya University Journal of Education, 4(1), 116-136. doi:10.19126/suje.76547

Padilla, M. J., McKenzie, D. L. \& Shaw Jr, E. L. (1986). An examination of the line graphing ability of students in grades seven through twelve. School Science and Mathematics, 86(1), 20-26.

Rubin, A., Hammerman, J. \& Konold, C. (2006). Exploring informal inference with interactive visualization software. Proceedings of the Seventh International Conference on Teaching Statistics. Netherlands.

Schield, M. (2010). Assessing Statistical Literacy: Take CARE. In P. Bidgood, N. Hunt, and F. Joliffe (Eds.), Assessment Methods in Statistical Education: An International Perspective (pp. 133-152). Chichester, UK: John Wiley \& Sons.

Schultz, J. E. \& Waters, M. S. (2000). Why representations?. Mathematics Teacher, 93(6), 448-453.

Shaughnessy, J. M. (1992). "Research in probability and statistics: reflections and directions”. In D.A. Groups, (Ed)., Handbook of Research on Mathematics Teaching and Learning, Macmillian 465-494, New York.

Shaughnessy, J. M., Garfield, J. \& Greer, B. (1996). Data handling. In A. J. Bishop, K. Clements, C. Keitel, J. Kilpatrick, \& C. Laborde (Ed.), International handbook of mathematics education (pp. 205-237). Dordrecht, The Netherlands: Kluwer Academic Publishers. doi:10.1007/978-94-009-1465-0_7

Sözbilir, M. \& Kutu, H. (2008). Development and Current Status of Science Education Research in Turkey. Essays in Education [Special issue], 1-22.

Şimşek, A., Özdamar, N., Uysal, Ö., Kobak, K., Berk, C., Kılıçer, T. ve Çiğdem, H. (2009). İkibinli yıllarda Türkiye'deki eğitim teknolojisi araştırmalarında gözlenen eğilimler. Kuram ve Uygulamada Ĕ̌itim Bilimleri Dergisi, 9(2), 945-966. 
Tatar, E., Kağızmanlı, T. B. ve Akkaya, A. (2013). Türkiye'deki teknoloji destekli matematik eğitimi araştırmalarının içerik analizi. Buca Ĕ̈itim Fakültesi Dergisi, 35, 33-50.

Türnüklü, A. (2000). Eğitimbilim araştırmalarında etkin olarak kullanılabilecek nitel bir araştırma tekniğgi: Görüşme. Kuram ve Uygulamada Egitim Yönetimi Dergisi, 6(4), 543-559.

Ulusoy, F. ve Çakıroğlu, E. (2013). İlköğretim matematik öğretmenlerinin histogram kavramına ilişkin kavrayışları ve bu kavramın öğretim sürecinde karşılaştıkları sorunlar. İlköğretim Online, 12(4), 11411156.

Van de Walle, J. A., Karp, K. S., \& Bay-Williams, J. M. (2010). Elementary and middle school mathematics: Teaching developmentally (7th Edition). United State: Pearson Education.

Yenilmez, K. ve Sölpük, N. (2014). Matematik dersi öğretim programı ile ilgili tezlerin incelenmesi (20042013), Ĕgitim ve Öğretim Araştırmaları Dergisi, 3(2), 33-42.

Yıldırım, A. ve Şimşek, H. (2005). Sosyal Bilimlerde Nitel Araştırma Yöntemleri. Ankara: Seçkin Yayınları. 


\section{Ek A}

\section{İncelenen Çalışmalar}

Akkaya, R. (2010). Olasılık ve istatistik öğrenme alanındaki kavramların gerçekçi matematik eğitimi ve yapılandırmacılık kuramına göre bilgi oluşturma sürecinin incelemesi (Yayımlanmamış doktora tezi). Uludağ Üniversitesi, Sosyal Bilimler Enstitüsü, Bursa.

Arı, E. ve Topçu, B. (2013). İlköğretim 6-7 ve 8. sınıflarında öğrenim gören öğrencilerin matematik dersinde istatistik ve olasılık konusuna karşı tutumlarının sınıf düzeyi bakımından değerlendirilmesi: Afyonkarahisar ili örneği. Erzincan University Journal of Science And Technology, 6(1), 87-98.

Arısoy, B. (2011). İşbirlikli öğrenme yönteminin ÖTBB ve TOT tekniklerinin 6. sinıf öğrencilerinin matematik dersi "istatistik ve olasılık" konusunda akademik başarı, kalıcılık ve sosyal beceri düzeylerine etkisi (Yayımlanmamıș yüksek lisans tezi). Çukurova Üniversitesi, Sosyal Bilimler Enstitüsü, Adana.

Berkün, N. D. (2016). Permütasyon ve olasılık konusunun öğretiminde bilgi değişme tekniğinin kullanılmasının akademik başarıya ve hatırda tutma düzeyine etkisinin incelenmesi (Yayımlanmamış yüksek lisans tezi). Anadolu Üniversitesi, Eğitim Bilimleri Enstitüsü, Eskişehir.

Besler, B. (2009). 8. Sinıf Matematik Dersi “Permütasyon ve Olasılık” Konusunun Öğretiminde Yapılandırmacı Yaklaşıma Uygun Olarak Hazırlanmış Çalışma Yapraklarının Öğrenci Başarısına Etkisi (Yayımlanmamış yüksek lisans tezi). Gazi Üniversitesi, Eğitim Bilimleri Enstitüsü, Ankara.

Cihan, E. (2017). Gerçekçi matematik eğitiminin olasılık ve istatistik öğrenme alanına iliş̧kin akademik başarı, motivasyon ve kalıcılık üzerindeki etkisi (Yayımlanmamış yüksek lisans tezi) Çukurova Üniversitesi, Sosyal Bilimler Enstitüsü, Adana.

Çakmak, Z. T. (2014). İlköğretim 6-8. sinıf matematik ögrencilerinin istatistik ve olasılı öğrenme alanında zorlandıkları kavram ve konuların belirlenmesi (Yayımlanmamış yüksek lisans tezi) Abant İzzet Baysal Üniversitesi, Eğitim Bilimleri Enstitüsü, Bolu.

Çakmak, Z. T. ve Durmuş, S. (2015). İlköğretim 6-8. sınıf öğrencilerinin istatistik ve olasılık öğrenme alanında zorlandıkları kavram ve konuların belirlenmesi. Abant İzzet Baysal Üniversitesi Ĕgitim Fakültesi Dergisi, 15(2), 27-58.

Çakmak, Z. Çetin, Ö. F. ve Bekdemir, M. (2016). Sekizinci sınıf öğrencilerinin istatistik konusundaki matematiksel dil becerilerinin yapısal eşitlik modeli ile incelenmesi. Ilköğretim Online, 15(2), 299-317. doi:10.17051/io.2016.73927

Çelik, H. (2010). İlköğretim 7. Sınıf Öğrencilerinin “Olasılık Ve İstatistik” Ünitesini Öğrenmeleri Üzerinde Bilgisayar Destekli Öğretimin Etkisi. Düzce Üniversitesi Sosyal Bilimler Enstitüsü Dergisi, 4(2), 45-64.

Çelik, H. C. ve Çevik, M. N. (2011). İlköğretim 7. slnıf öğrencilerinin “istatistik ve olasılık” ünitesini öğrenmeleri üzerinde bilgisayar destekli ögretimin etkisi. In 5th International Computer \& Instructional Technologies Symposium, Elazığ.

Çimenci, F. A. (2016). Ortaokul 8. sınıf öğrencilerinin matematik dersine yönelik kaygl, tutum ve öz-yeterlilik inançlarının grafik okuma ve yorumlama başarı düzeylerine etkisinin değerlendirilmesi incelenmesi (Yayımlanmamış yüksek lisans tezi). Afyon Kocatepe Üniversitesi, Sosyal Bilimler Enstitüsü, Afyon.

Çubuk, Ş. (2004). Matematik ögretiminde 'permütasyon ve olasılık' konusunun bilgisayar destekli öğretim materyalleri ile ögretilmesinin öğrenci bașarısına etkisi (Yayımlanmamıș yüksek lisans tezi). Marmara Üniversitesi, Eğitim Bilimleri Enstitüsü, İstanbul.

Dereli, A. (2009). Sekizinci Sını öğrencilerinin olasılık konusundaki hataları ve kavram yanılgıları (Yayımlanmamış yüksek lisans tezi). Eskişehir Osmangazi Üniversitesi Fen Bilimleri Enstitüsü, Eskişehir.

Duran, M. Doruk, M. ve Kaplan, A. (2017). Argümantasyon tabanlı olasılık öğretiminin ortaokul öğrencilerinin başarılarına ve kaygılarına etkililiğinin incelenmesi. Eğitimde Kuram ve Uygulama, 13(1), 55-87.

Duran, M., Özdemir, F., ve Kaplan, A. (2015). Probleme dayalı öğrenme yaklaşımının kullanımına yönelik bir araştırma: olasılık konularının öğretimi örneği. Turkish Journal of Computer and Mathematics Education (TURCOMAT), 6(2), 250-284.

Efe, M. (2011). İşbirlikli öğrenme yönteminin, öğrenci takımları başarı bölümleri ve küme destekli bireyselleştirme tekniklerinin ilköğretim 7. sinıf öğrencilerinin matematik dersi "istatistik ve olasıllk" ünitesindeki başarılarına, tutumlarına ve motivasyonlarına etkisi (Yayımlanmamış yüksek lisans tezi). Mustafa Kemal Üniversitesi, Sosyal Bilimler Enstitüsü, Hatay.

Ekinözü, İ. (2003). İlköğretimde Permütasyon ve Olasılık Konusunun Dramatizasyon İle Öğretiminin Başarıya Etkisinin Incelenmesi (Yayımlanmamış yüksek lisans tezi). Marmara Üniversitesi Eğitim Bilimleri Enstitüsü, İstanbul.

Ekinözü, İ. ve Şengül, S. (2007). Permütasyon ve olasılık konusunun öğretiminde canlandırma kullanılmasının öğrenci başarısına ve hatırlama düzeyine etkisi. Kastamonu Eğitim Dergisi, 15(1), 251-258.

Erbilgin, E., Arıkan, S. ve Yabanlı, H. (2015). Çizgi Grafiğini Yorumlama ve Oluşturma Becerilerinin Ölçülmesi. Kırşehir Ĕ̌itim Fakültesi Dergisi, 16(2), 43-61. 
Ercan, Ö. (2008). Çoklu Zekâ Kuramına Dayalı Öğretim Etkinliklerinin 8. Sinıf Öğrencilerinin Matematik Dersi "Permütasyon Ve Olasılık" Ünitesindeki Akademik Başarılarına Etkisi (Yayımlanmamış yüksek lisans tezi). Gazi Üniversitesi, Eğitim Bilimleri Enstitüsü, Ankara.

Erdem, E. (2011). Illköğretim 7. sinıf öğrencilerinin matematiksel ve olasılıksal muhakeme becerilerinin incelenmesi (Yayımlanmamış yüksek lisans tezi). Adıyaman Üniversitesi, Fen Bilimleri Enstitüsü, Adıyaman.

Ersoy, E. (2013). Gerçekçi matematik eğitimi destekli ögrretim yönteminin 7.sınıf olasılık ve istatistik kazanımlarının ögretiminde öğrenci başarısına etkisi (Yayımlanmamış yüksek lisans tezi). Sakarya Üniversitesi, Eğitim Bilimleri Enstitüsü, Sakarya.

Ertem, S. (2007). Veri toplama ve değerlendirme ünitesinin, ilköğretim öğrencilerinin bilimsel tutum geliştirmelerine katkl getirecek şekilde yeniden düzenlenmesi (Yayımlanmamış doktora tezi). Dokuz Eylül Üniversitesi, Eğitim Bilimleri Enstitüsü, İzmir.

Esen, B. (2009). Matematik ĕgitiminde ilköğretim 6. sinıflarda olasıllk konusunun öğretiminde bilgisayar destekli eğitimin rolü (Yayımlanmamış yüksek lisans tezi). Selçuk Üniversitesi, Fen Bilimleri Enstitüsü, Konya.

Fırat, S. (2011). Bilgisayar destekli eğitsel oyunlarla gerçekleştirilen matematik ögretiminin kavramsal öğrenmeye etkisi (Yayımlanmamış yüksek lisans tezi). Adıyaman Üniversitesi, Fen Bilimleri Enstitüsü, Adıyaman.

Güner, N. (2015). 6.-8. sınıf matematik ders kitaplarındaki geometri, veri ve olasılık sorularının TIMSS bilişsel düzeylerine göre sinıflandırılması. Pamukkale Üniversitesi Eğitim Fakültesi Dergisi, 37(37), 77-90. doi:10.9779/PUJE710

Gürakar, N. (2010). İlköğretim 6-8. sınıf öğrencilerinin istatistik temsil biçimlerini kullanma becerilerinin belirlenmesi (Yayımlanmamış yüksek lisans tezi). Abant İzzet Baysal Üniversitesi, Sosyal Bilimler Enstitüsü, Bolu.

Gürbüz, R. (2006). Olasılık kavramlarının öğretimi için örnek çalışma yapraklarının geliştirilmesi. Çukurova Üniversitesi Eğitim Fakültesi Dergisi, 31(1), 111-123.

Gürbüz, R., Çatlığlu, H., Birgin, O. ve Erdem, E. (2010). Etkinlik temelli öğretimin 5. sınıf öğrencilerinin bazı olasılık kavramlarındaki gelișimlerine etkisi: Yarı deneysel bir çalıșma. Kuram ve Uygulamada Eğitim Bilimleri, 10(2), 10211069.

Gürsoy, K., Güler, M., ve Çelik, R. (2014). Ortaokul 7. ve 8. sınıf öğrencilerinin istatistiğe karșı tutumlarının çeşitli değişkenler açısından incelenmesi. Turkish Journal of Computer and Mathematics Education (TURCOMAT), 5(1), 6072.

Güven, B. ve Koparan T. (2014). Proje Tabanlı Öğrenme Yaklaşımının Öğrencilerin Olasılık Kavramına Yönelik İstatistiksel Okuryazarlık Seviyelerine Etkisi. Eğitim ve Öğretim Araşstırmaları Dergisi, 3(1), 60-84. doi:10.17051/io.2014.45537

Güven, B., Öztürk, T. ve Özmen, Z. M. (2015). Ortaokul Sekizinci Sınıf Öğrencilerinin İstatistiksel Süreçteki Deneyimlerinin İncelenmesi. Eğitim ve Bilim, 40(177), 343-363. doi:10.15390/EB.2015.3313

Hacısalihoğlu-Karadeniz, M. (2016). Beşinci sınıf öğrencilerinin veri işleme konusundaki kazanımlara ulaşabilme durumlarının belirlenmesi. Akdeniz Insani Bilimler Dergisi, 4(1), 221-236. doi:10.13114/MJH.2016119300

Hayat, F. (2009). İlköğretim 8. sınıf öğrencilerinin olasılıkla ilgili kavramsal ve işlemsel bilgi düzeyleri ve kavram yanılgılarının belirlenmesi (Yayımlanmamış yüksek lisans tezi). Atatürk Üniversitesi, Fen Bilimleri Enstitüsü, Erzurum.

Işık, A., ve Özdemir, G. (2014). Çalışma Yapraklarıyla Olasılık Öğretiminin Öğrenci Başarısına Etkisi. Middle Eastern \& African Journal of Educational Research MAJER, 12, 4-16.

Katranc1, Y. ve Altun, M. (2013). İlköğretim İkinci Kademe Öğrencilerinin Olasılık Bilgisini Oluşturma ve Pekiştirme Süreci. Kalem Eğitim ve İnsan Bilimleri Dergisi, 3(2), 11-58.

Kaynar, Y. (2012). Yeni ilköğretim II. kademe matematik öğretim programının istatistik boyutunun incelenmesi (Yayımlanmamış yüksek lisans tezi). Afyon Kocatepe Üniversitesi, Sosyal Bilimler Enstitüsü, Afyon.

Keskin, S. ve Kılıç, D. (2016). Ortaokul 7. Sınıf Matematik Dersinde Olasılık Konusunun İşbirlikli Öğrenme Yöntemiyle Öğretiminin Öğrencilerin Akademik Başarılarına Etkisi. Atatürk Üniversitesi Sosyal Bilimler Enstitüsü Dergisi, 20(3),1173-1183.

Koparan, T. ve Güven, B. (2013). İlköğretim İkinci kademe öğrencilerinin istatistiksel düşünme seviyelerindeki farklılaşma üzerine bir araştırma. Illkögretim Online, 12(1), 158-178.

Koparan, T. ve Güven, B. (2014). 8. Sınıf Öğrencilerinin Örneklem Kavramına Yönelik İstatistiksel Okuryazarlık Seviyelerinin Belirlenmesi. Ilköğretim Online, 13(4).

Koparan, T. ve Güven, B. (2014). Proje Tabanlı Öğrenmenin Öğrencilerin Çıkarıma Yönelik İstatistiksel Okuryazarlık Seviyelerine Etkisi. Karaelmas Eğitim Bilimleri Dergisi, 2(1), 33-48.

Koparan, T. ve Güven, B. (2014). Ortaokul Öğrencilerinin İstatistiksel Düşünme Seviyelerinin M3ST Modeline Göre İncelenmesi. Ĕgitim ve Bilim, 39(171), 37-51. 
Laçin, F. (2014). Kavram haritası ve vee diyagramının ilköğretim 8. sınıf istatistik ve olasılık konusunda ögrenci başarısına ve tutumuna etkisi (Yayımlanmamış yüksek lisans tezi). Zirve Üniversitesi, Sosyal Bilimler Enstitüsü, Gaziantep.

Memnun, D. S. (2008). Sekizinci sınıfta permütasyon ve olasılık konularının aktif öğrenme ile öğretiminin uygulama düzeyi öğrenci başarısına etkisi. İnönü Üniversitesi Ĕgitim Fakültesi Dergisi, 21 (2), 403-426.

Memnun, D. S., Altun, M. ve Yılmaz, A. (2010). İlköğretim sekizinci sınıf öğrencilerinin olasılıkla ilgili temel kavramları anlama düzeyleri. Uludă̆ Üniversitesi Ĕ̈itim Fakültesi Dergisi, 23(1), 11-29.

Memnun, S. (2013). Ortaokul yedinci sınıf öğrencilerinin çizgi grafik okuma ve çizme becerilerinin incelenmesi. Electronic Turkish Studies, 8(12), 1153-1167.

Özbay, S. (2012). İnformel çıkarsamalı akıl yürütmede ögrencilerin örneklem hakkındaki akll yürütme ve düşünme süreçleri (Yayımlanmamış yüksek lisans tezi). Pamukkale Üniversitesi Fen Bilimleri Enstitüsü, Denizli.

Selamet, C. S. (2014). Beşinci sınıf ögrencilerinin tablo ve grafik okuma ve yorumlama başarı düzeylerinin incelenmesi (Yayımlanmamış yüksek lisans tezi). Afyon Kocatepe Üniversitesi, Sosyal Bilimler Enstitüsü, Afyon.

Seyhanlı, S. S. (2017). Graf teorisinin ilköğretim 8.sınıf olasıllk konusunun öğretiminde öğrenci başarısına etkisi (Yayımlanmamış yüksek lisans tezi). Balıkesir Üniversitesi, Fen Bilimleri Enstitüsü, Balıkesir.

Şan, İ. (2014). 7. sınıf matematik dersi olasılık ve istatistik öğrenme alanının öğretiminde 'Sinav yoluyla ögrrenme yönteminin ögrencilerin akademik başarı, tutum ve sınav kaygısına etkisi (Yayımlanmamış doktora tezi). İnönü Üniversitesi, Eğitim Bilimleri Enstitüsü, Malatya.

Şengül, S. ve Katrancı, Y. (2013). İlköğretim 6. sınıf öğrencilerinin "tablo ve grafikler” konusu ile ilgili yakınsal gelişim alanlarının belirlenmesi. International Journal of Social Science, 6(5), 633-665. doi:10.9761/JASSS519

Toluk, Uçar, Z. ve Akdoğan, E. N. (2009). 6-8. Sınıf Öğrencilerinin Ortalama Kavramına Yüklediği Anlamlar. İlköğretim Online, 8(2), 391-400.

Tuncer, T. (2011). Matematik dersi yedinci sınıf "permütasyon ve olasıllı" konusunda uygulanan üst bilişs stratejilerinin, ögrencilerin başarılarına, üst biliş becerilerine, tutumlarına ve kalıcılığa etkisi (Yayımlanmamış yüksek lisans tezi). Atatürk Üniversitesi Eğitim Bilimleri Enstitüsü, Erzurum.

Ünlü, M. (2008). İşbirlikli ögrretim yönteminin 8. sinıf ögrrencilerinin matematik dersi "permütasyon ve olasıllk" konusunda akademik başarı ve kalıcılık düzeylerine etkisi (Yayımlanmamış yüksek lisans tezi). Gazi Üniversitesi, Eğitim Bilimleri Enstitüsü, Ankara.

Ünlü, M. ve Aydıntan, S. (2011). İşbirlikli öğrenme yönteminin 8. sınıf öğrencilerinin matematik dersi "permütasyon ve olasılık" konusunda akademik başarı ve kalıcılık düzeylerine etkisi. Ahi Evran Üniversitesi Kırşehir Eğitim Fakültesi Dergisi, 12(3), 1-16.

Yabanlı, H., Yıldırım, B. ve Günaydın, Ö. (2013). Haritadan çizgi grafiğine. Araştırma Temelli Etkinlik Dergisi, 3(1), 12-19.

Yanık, H. B., Özdemir, G. ve Çevirgen, A. E. (2017). Ortaokul Matematik Ders Kitaplarında Yer Alan Veri İşlemeye Yönelik Görevlerin İncelenmesi. İn̈nü Üniversitesi Ĕ̆itim Fakültesi Dergisi, 18(2), 45-61.

Yayla, G. ve Özsevgeç, T. (2016). Ortaokul Öğrencilerinin Grafik Becerilerinin İncelenmesi: Çizgi Grafikleri Oluşturma Ve Yorumlama. Kastamonu Eğitim Dergisi, 23(3), 1381-1400.

Yıldırım, D. ve Albayrak, Y . (2016). Ortaokul Öğrencilerinin Farklı Temsil Biçimlerine Göre Doğrusal İlişki Konusunu Anlama Düzeylerinin İncelenmesi. Adnan Menderes Üniversitesi Ĕgitim Fakültesi Ĕgitim Bilimleri Dergisi, 7(2), 1126.

Yılmaz, N. ve Ay, S. P. (2016). Sekizinci Sınıf Öğrencilerinin Histogram Grafiğini Yapılandırma, Anlamlandırma ve Yorumlama Sürecine İlişkin Bir Durum Çalışması. İlköğretim Online, 15(4). doi:10.17051/io.2016.66174 